\title{
Thyroid Carcinoma in Children and Young Adults: Retrospective Review of 19 Cases
}

\author{
Carcinoma da Tiróide em Crianças e Jovens Adultos: \\ Revisão Retrospectiva de 19 Casos
}

\author{
Joana SARAIVA ${ }^{1}$, Cristina RIBEIRO ${ }^{1}$, Miguel MELO ${ }^{1}$, Leonor GOMES ${ }^{1}$, Gracinda COSTA $^{2}$, Francisco CARRILHO ${ }^{1}$ \\ Acta Med Port 2013 Sep-Oct;26(5):578-582
}

\section{ABSTRACT}

Introduction: Thyroid carcinoma is rare in children and young adults. Most of management guidelines are based in data from adult population. Several controversies remain regarding the aggressiveness of clinical presentation and therapeutic approach.

Objective: To evaluate all differentiated thyroid carcinoma patients with less than 20 years-old at presentation reflecting the experience of our unit in relation to diagnosis, treatment and follow-up of this clinical entity.

Material and Methods: This is a retrospective review of clinical records of all children and young adults followed at Oncology Consultation of Department of Endocrinology of Centro Hospitalar e Universitário de Coimbra between 1996 and 2012.

Results: Nineteen patients with mean age of 16 years old were followed, 13 girls and 6 boys. None of the patients had previous neck irradiation. A palpable cervical mass was the presenting complaint in $84.6 \%$. FNA was performed in 15 patients and was diagnostic or suspicious of malignancy in $71.4 \%$. Total thyroidectomy was performed in 18 cases $(94.7 \%)$. Papillary carcinoma was identified in all. Vascular invasion and multicentry occurred in $21.1 \%$. Mean tumor size was $2.5 \mathrm{~cm}$. Cervical lymph node involvement was diagnosed in $31.6 \%$ and distant metastases in $5.2 \%$. The majority of patients (18 in 19) were classified as stage I disease. All patients received thyroxine suppressive therapy and postoperative radioiodine ablation was given to $84.2 \%$ (mean dose $85.7 \mathrm{mCi}$ ). During mean follow-up of almost 6 years, 16 patients remain disease free.

Conclusion: In our series, cervical lymph node and distant metastases rates were similar to that found in adult population. Overall prognosis was very good.

Keywords: Thyroid Neoplasms; Adolescent; Child; Retrospective Studies.

\section{RESUMO}

Introdução: O carcinoma da tiróide é raro em crianças e em adultos jovens. A maior parte das orientações clínicas baseia-se em dados obtidos na população adulta. Persistem diversas controvérsias no que se refere à agressividade da apresentação clínica e da abordagem terapêutica.

Objectivo: Avaliar todos os doentes com carcinoma da tiróide com menos de 20 anos no momento da apresentação, reflectindo a experiência da nossa unidade relativamente ao diagnóstico, tratamento e seguimento desta entidade.

Material e Métodos: Trata-se de um estudo de revisão retrospectiva dos registos clínicos de todas as crianças e adultos jovens seguidos na Consulta de Oncologia do Serviço de Endocrinologia do Centro Hospitalar e Universitário de Coimbra entre 1996 e 2012.

Resultados: Foram estudados 19 doentes, com uma média etária de 16 anos, sendo 13 do sexo feminino. Nenhum dos doentes fora previamente submetido a irradiação da região do pescoço. A queixa de apresentação era a presença de uma massa cervical palpável em $84,6 \%$ dos casos. Foi realizada citologia aspirativa em 15 doentes, que foi diagnóstica ou suspeita de neoplasia em $71,4 \%$ dos casos. A tiroidectomia total foi levada a cabo em 18 casos (94,7\%). Em todos estes foi identificada a presença de um carcinoma papilar. A invasão vascular e multicêntrica ocorreu em $21,1 \%$ dos casos. A dimensão tumoral média foi de $2,5 \mathrm{~cm}$. $O$ envolvimento ganglionar cervical foi diagnosticado em $31,6 \%$ dos casos e a presença de metástases à distância foi identificada em $5,2 \%$ dos casos. Na maior parte dos doentes (18 em 19), o quadro foi classificado como doença em estadio I. Todos os doentes fizeram terapêutica supressora com tiroxina e $84,2 \%$ dos doentes foram submetidos a ablação pós-operatória com iodo radioactivo (dose média de $85,7 \mathrm{mCi}$ ). Durante um seguimento médio de cerca de 6 anos, 16 doentes permaneceram em remissão.

Conclusão: Na nossa série, as taxas de metastização ganglionar cervical e à distância foram semelhantes às encontradas na população adulta. O prognóstico foi globalmente muito satisfatório.

Palavras-chave: Neoplasias da Tiróide; Adolescente; Criança; Estudos Retrospectivos.

\section{INTRODUCTION}

Thyroid carcinoma is rare in pediatric age, accounting for 1.5 to $3 \%$ of all childhood cancers in North America and Europe, but it's incidence is increasing by $1.1 \%$ per year. ${ }^{1,2}$ It's very uncommon before age of 10 years, with an annual incidence of one per million, increases rapidly after adolescence where it's prevalence may reach $13 \% .^{2-5}$ Most thyroid nodules in children are benign and recent studies suggest that less than $1 \%$ are malignant. ${ }^{6}$ This is in contrast with older studies that report malignancy rates between 2 to $40 \%$ and likely represent 'referral bias' of children with increased risk factors for thyroid cancer. ${ }^{6}$ In this population more than $90 \%$ of follicular cell-derived thyroid carcinomas are papillary (PTC) and variants such follicular and diffuse sclerosing are frequent. ${ }^{4}$ lonizing radiation remains the major risk factor for developing PTC but in most cases, specific risk factors cannot be identified. ${ }^{5,7}$ Familial history is also a risk factor in approximately $5 \%$ of children. ${ }^{8}$ Studies in younger have revealed differences in molecular biology of these

1. Department of Endocrinology. Centro Hospitalar e Universitário de Coimbra. Coimbra. Portugal.

2. Department of Nuclear Medicine. Centro Hospitalar e Universitário de Coimbra. Coimbra. Portugal.

Recebido: 22 de Janeiro de 2013 - Aceite: 29 de Maio de 2013 | Copyright @ Ordem dos Médicos 2013 
tumors. ${ }^{5,7}$ In children RET/PTC rearrangements have a higher prevalence. ${ }^{7}$ Particularly, RET/PTC3 is more common in patients with radiation-induced PTC and is associated with solid variant with short latency period and more aggressive clinical behavior. ${ }^{7}$ BRAF mutations are infrequent in children with differentiated thyroid carcinoma. ${ }^{7}$ Also, metastatic focus in children expresses high levels of sodium-iodide transporter (NIS) which results in greater responsiveness to radioiodine treatment (RAI) and better prognosis. ${ }^{5}$ Treatment options are similar between children and adults and are based in combination of three therapeutic modalities: surgery, hormone replacement with levothyroxine (LT4) and radiodine treatment. Controversies regarding the ideal therapeutic approach remain among the scientific community and current recommendations and staging systems are based on data generated by studies on adults. ${ }^{5}$ Despite its aggressive presentation and higher recurrence rates, long term prognosis is excellent in this age group. As so, therapy should minimize treatment and disease related morbidity. ${ }^{9}$ The aim of this retrospective study is to evaluate all differentiated thyroid carcinoma patients with less than 20 years-old followed at Department of Endocrinology of Centro Hospitalar e Universitário de Coimbra (CHUC).

\section{MATERIAL AND METHODS}

Nineteen patients with 20-years old or less were diagnosed with DTC in our institution between 1996 and 2012. Patient's health care records were reviewed to determine demographic data, clinical presentation, risk factors, family history, preoperative thyroid function, treatment interventions and follow-up. Five patients were operated in other institutions and referred to our Department for follow-up after pathology result. Endocrinology department of CHUC has a highly differentiated thyroid oncology consultation. Tumor staging was performed based on the TNM (tumornode-metastases) tumor classification system ${ }^{9}$ and was assessed using data collected after thyroidectomy. Radioiodine ablative therapy was proposed to all patients, except if microcarcinoma. Ablation dose of ${ }^{131}$ I was calculated on an individual basis. Levothyroxine treatment was adjusted to suppression of TSH to less than $0.1 \mathrm{mU} / \mathrm{L}$. Follow-up of this patients include regular appointments for clinical evaluation and monitoring with thyroglobulin ( $\mathrm{Tg}$ ) assays and cervical ultrasonography (US).

\section{RESULTS}

Nineteen patients with age up to 20 years-old were identified: 13 girls and 6 boys, representing a ratio of 1:2.2 male/female. Patients' characteristics are resumed in Table 1. The age of the patients at the time of the diagnosis of thyroid carcinoma ranged from 9 to 20 years (mean $16 \pm 3.4$ years). Patients were followed during a mean period of six years. None of the patients had a history of head or neck irradiation. Five patients had autoimmune thyroiditis medicated with levothyroxine. One patient's mother had had papillary thyroid carcinoma. A palpable cervical mass was the principal sign to call attention in twelve patients; a palpable adenomegaly was identified in two; in four patients the diagnosis was made incidentally during routine medical exam. No data available in one case. Sixteen patients had US results. Fourteen showed the presence of iso and hypoechogenic thyroid nodules, including three with microcalcifications and one with associated cervical adenopathy. One had goiter and cervical adenopathy, and another with diffuse increase in right lobe. Data concerning US results were missing in three cases. The nodule's dimension ranged from 0.5 to 4.1 $\mathrm{cm}$ (mean $2.3 \mathrm{~cm}$ ). Results of fine needle aspiration (FNA) were available in sixteen patients (fourteen of thyroid nodule and two of suspicious cervical lymph node). Thyroid nodule FNA was diagnostic or suspicious of malignancy in 10 patients $(71.4 \%)$, two $(14.2 \%)$ had follicular tumor; a benign result (colloid) was identified in two of the patients (14.2\%), in one of this cases FNA was repeated under US control. Lymph node FNA was positive for papillary thyroid carcinoma in one patient. Total thyroidectomy (TT) was performed in eighteen patients $(94.7 \%)$. Seven patients were treated initially with lobectomy and six underwent a second surgical procedure after review of the final pathology result of initial procedure. Unilateral lymph node dissection was performed in seven patients. Four patients had postoperative transient hypocalcemia and one had simultaneously transient hoarseness. All cases corresponded to papillary thyroid carcinoma. The majority $(57.9 \%)$ was classic. Three $(15.8 \%)$ had follicular variant and two (10.5\%) had microcarcinoma (tumor with less than $1 \mathrm{~cm}$ ). Rare variants were identified in three cases: diffuse sclerosing, solid growth pattern and Warthin like. Multicentry occurred in four patients $(21.1 \%)$. Mean tumor size ( $n=18$ ) was $2.5 \mathrm{~cm}$ (range 0.1 to $6.5 \mathrm{~cm}$ ), with two (10.5\%) microcarcinomas (tumor with less than 1 $\mathrm{cm})$. Vascular invasion was seen in four cases $(21.1 \%)$ and thyroid capsular invasion in five $(26.3 \%)$. Cervical lymph node metastases occurred in six patients (31.6\%). Postoperative radiodine ablation was given to sixteen patients $(84.2 \%)$, in all unless microcarcinoma and if refused (case number 2) on average 3.4 months after surgery (in one only six years after). The initial amount of ${ }^{131}$ I that was administered ranged from 60 to $126 \mathrm{mCi}$ (mean 85.7). Post-therapeutic whole body scintigraphy was performed seven days after ${ }^{131}$ I, all patients presented with thyroid remnants, four with lymph node spread and one with pulmonary metastases. All patients were submitted to levothyroxine therapy in suppressive doses. Six patients underwent additional ${ }^{131}$ | treatment (between one to four treatments). Mean cumulative radiodiodine dose was $198 \mathrm{mCi}$ (range 60 to 874). During mean follow-up of almost six years, $84.2 \%$ of patients remain free of disease. In one case (patient number 3 ) lymph node recurrence was detected after third radioiodine treatment but without suspicious images in last cervical US and thoracic TC, with $\mathrm{Tg}$ of $1.9 \mathrm{ng} / \mathrm{dL}$ under suppressive LT4. A girl (patient number 5 ) with disseminated pulmonary metastases was submitted to four $131 \mathrm{l}$ therapies during two and half years, with mean cumulative dose of $874 \mathrm{mCi}$, and also to upper left lung lobectomy. It was verified significative reduction of the number and dimension of pulmonary 
lesions, with a progressive $\mathrm{Tg}$ reduction to $42 \mathrm{ng} / \mathrm{dL}$ under LT4 suppression. In last evaluation two patients (numbers 3 and 12) had positive $\mathrm{Tg}$ with negative image. In this series, patients with rare and potential more aggressive histological variants (cases 4 and 18) showed, so far, good clinical evolution with no recurrence (Table 1).

\section{DISCUSSION}

Differentiated thyroid carcinoma is an uncommon disease in children and young adults. Most works agree that the clinical course of thyroid carcinoma in this age group is different than the clinical course in adults. Tumor volume tends to be larger in patients less than 20 years old and early involvement of thyroid capsule and surrounding tissue is seen, probably due to gland small volume. ${ }^{5}$ Multicentricity is also more frequent. Children present with more extensive disease, 40 to $90 \%$ present with lymph node involvement at diagnosis (compared to $20-50 \%$ of adults) and $20-30 \%$ with distant metastases, most commonly lung (versus $2 \%$ in adults). ${ }^{5,7}$ Although, Lazar et al verified that patients diagnosed after 1970 had less local invasion and lower incidence of lymph node involvement and lung metastases, likely result of a precocity in diagnosis. ${ }^{10}$ But, despite children present with more advanced stages of disease and higher recurrence rates, the overall prognosis is excellent.

Epidemiologic data in Portugal is missing. Two Portu- guese centers found 2.3 and 2.2 cases/year in patients under 18 years old. ${ }^{11,12}$ In our institution during the last 16 years we diagnosed and followed 19 young patients. The female to male ratio is in accordance to literature, that refers prepubertal rates similar in boys and girls, after puberty ratio may reaches 2.5-6:1.4,7 We couldn't find significant difference in clinical presentation between boys and girls. None of the patients had a history of head or neck irradiation. In the majority $(84.6 \%)$ the initial complaint was a palpable cervical mass, the most common presentation form described. ${ }^{4,5,7}$ The evaluation of thyroid nodules in children remains controversial. ${ }^{13}$ Few centers have adequate experience to document the positive and negative predictive value of FNA for children but it seems to have a similar specificity and sensitivity as in adults. ${ }^{13}$ In this review, FNA of thyroid nodule was diagnostic or suspicious of malignancy in $71.4 \%$. There were two cases of false negative values. In seven patients the initial surgical procedure was lobectomy (mostly in cases where FNA findings were benign or follicular tumor), which lead to the necessity for a second intervention in six of them after pathology results. Some authors defend less aggressive management given the excellent prognosis of this disease and the risk of treatment morbidity. ${ }^{13}$ It seems that total or near total thyroidectomy reduces recurrence risk even in cases of unilateral and solitary nodule with no regional or distant metastases or risk

Table 1 - Summary of epidemiologic, clinical and pathological data of 19 children with PTC.

\begin{tabular}{|c|c|c|c|c|c|c|c|c|c|c|}
\hline $\begin{array}{c}\text { Case } \\
n^{\circ}\end{array}$ & Gender & $\begin{array}{l}\text { Age } \\
\text { (yr) }\end{array}$ & $\begin{array}{l}\text { Tm } \\
\text { size } \\
(\mathbf{c m})\end{array}$ & Surgery & TNM & $\begin{array}{c}\text { Metastatic } \\
\text { spread }\end{array}$ & Recurrence & $\begin{array}{c}131 \mathrm{I} \\
\text { Treatment }\end{array}$ & $\begin{array}{c}\text { Follow-up } \\
\text { duration } \\
(y r)\end{array}$ & $\begin{array}{l}\text { Additional } \\
\text { information }\end{array}$ \\
\hline 1 & $\mathrm{~F}$ & 16 & 0.1 & $L+1$ & T1NxMx & No & No & 0 & 6 & $\mathrm{AlT}$ \\
\hline 2 & $\mathrm{~F}$ & 11 & 1.2 & TT+LND & T1N0Mx & No & No & 0 & 1 & $\mathrm{AlT}$ \\
\hline 3 & $\mathrm{~F}$ & 13 & 2.0 & $\mathrm{TT}$ & T1NxMx & No & Yes (LN) & 3 & 8 & \\
\hline 4 & $\mathrm{~F}$ & 13 & 3.6 & TT+LND & T3N1Mx & LN & No & 1 & 1 & $\begin{array}{c}\text { Diffuse } \\
\text { sclerosing } \\
\text { variant }\end{array}$ \\
\hline 5 & $\mathrm{~F}$ & 15 & 4.0 & $\mathrm{TT}(2)$ & T3NxM1 & Pulmonar & No & 5 & 4 & \\
\hline 6 & $\mathrm{~F}$ & 17 & 3.6 & $\mathrm{TT}(2)+\mathrm{LND}$ & T2N1Mx & LN & No & 2 & 4 & $\begin{array}{c}\text { Warthin like } \\
\text { variant }\end{array}$ \\
\hline 7 & $\mathrm{~F}$ & 10 & a) & $\mathrm{TT}+\mathrm{LND}$ & T4N1bMx & LN & No & 3 & 13 & $\mathrm{Al} \mathrm{T}$ \\
\hline 8 & $\mathrm{~F}$ & 15 & 1.8 & $\mathrm{TT}(2)$ & T1NxMx & No & No & 1 & 1 & \\
\hline 9 & $\mathrm{~F}$ & 16 & 5.0 & $\mathrm{TT}+\mathrm{LND}$ & $\mathrm{T} 3(\mathrm{~m}) \mathrm{N} 1 \mathrm{Mx}$ & LN & No & 1 & 7 & \\
\hline 10 & M & 9 & 2.0 & $\mathrm{TT}(2)$ & T2NxMx & No & No & 1 & 15 & \\
\hline 11 & M & 17 & 1.7 & $\mathrm{TT}$ & T3(m)NxMx & No & No & 1 & 5 & \\
\hline 12 & $\mathrm{~F}$ & 18 & 6.5 & $\mathrm{TT}+\mathrm{LND}$ & T3N1M0 & LN & No & 3 & 16 & \\
\hline 13 & M & 19 & 1.5 & TT+LND & $\mathrm{T} 3(\mathrm{~m}) \mathrm{N} 1 \mathrm{Mx}$ & LN & No & 2 & 8 & \\
\hline 14 & $\mathrm{~F}$ & 19 & 1.2 & $\mathrm{TT}$ & T1NxMx & No & No & 1 & 3 & $\mathrm{AlT}$ \\
\hline 15 & $\mathrm{~F}$ & 19 & 1.6 & $\mathrm{TT}$ & T1NxMx & No & No & 1 & 3 & $\mathrm{AlT}$ \\
\hline 16 & M & 16 & 3.9 & $\mathrm{TT}(2)$ & T2NxMx & No & No & 1 & 1 & \\
\hline 17 & M & 20 & 0.8 & $\mathrm{TT}$ & T1NxMx & No & No & 0 & 4 & \\
\hline 18 & $\mathrm{~F}$ & 20 & 3.0 & TT & $\mathrm{T} 2(\mathrm{~m}) \mathrm{N} x \mathrm{Mx}$ & No & No & 1 & 5 & Solid \\
\hline 19 & $M$ & 20 & 1.8 & $\mathrm{TT}(2)$ & $\mathrm{T} 2 \mathrm{~N} x \mathrm{Mx}$ & No & No & 1 & 8 & \\
\hline
\end{tabular}


factors. ${ }^{7,10,13}$ The only patient in this series that didn't complete thyroidectomy had a papillary microcarcinoma with $0.1 \mathrm{~cm}$. Six year follow-up was negative for recurrence in this case. The value of lymph node dissection for children with PTC has not been well studied. Given the higher rate of lymph node dissemination in this population Rivkees et al recommend total or near total thyroidectomy along with central compartment lymph node dissection as part of the initial operation. ${ }^{7}$ Its not known if a correct preoperative US might detect this involvement limiting the value of node dissection. ${ }^{13}$ Latest ATA guidelines (2009) refer that, in adults, prophylactic central neck dissection may not be necessary in small (T1 or T2) non-invasive, clinically node-negative $\mathrm{PTC}^{9}$. In pediatric population this issue it's not addressed. In the cohort presented, cervical dissection was performed in 7 patients and was positive in 6 . This corresponds to a $31.5 \%$ of cases of cervical lymph node metastasis at presentation. Also, we had only one case of distant metastasis $(2.6 \%)$. This can be explained by the cohort median age, adding that almost all patients had more than 10 years-old. According to literature, age at presentation and extent disease are the most significant prognostic factors for thyroid cancer. ${ }^{4}$ PTC is more aggressive when diagnosed before the age of 10 years. In older children and adolescents the initial extent of disease and outcome are similar to those observed in young adults. ${ }^{4}$ Radioiodine ablation was performed in $84 \%$ of the patients. The use of radioactive iodine ablation for treatment of children with thyroid carcinoma remains controversial. There are no randomized studies comparing RAl application versus no-RAl for remnant ablation in children, but there are several arguments in favor. Most authors recommend that most children should be treated with RAI to ablate residual disease and reduce the risk of disease recurrence. ${ }^{7}$ Good results were achieved in these patients with a mean dosage of $85.7 \mathrm{mCi}$ without reported adverse effects. An important component in therapy is thyroid hormone suppression with LT4 which is associated with reductions in the risk of growth or tumor proliferation induced by TSH. Baudin et al recommend initial suppression of TSH to less than $0.1 \mathrm{mU} / \mathrm{L}$ followed by relaxation to $0.5 \mathrm{mU} / \mathrm{L}$ once patients enter remission, but bearing in mind that it may be difficult to enforce in pediatric population..$^{7,14}$ Risk assessment is very important component of DTC management. Actually AJCC/UICC is the most used system

\section{REFERENCES}

1. Greenlee RT, Hill-Harmon MB, Murray T, Thun M. Cancer statistics, 2001. CA Cancer J Clin. 2001;51:15-36.

2. Bleyer A, O'Leary M, Barr R, Ries LA. 2006 Cancer Epidemiology in older adolescents and young adults 15 to 29 years of age, including SEER incidence and survival: 1975-200. National Cancer Institute, NIH Pub. No 06-5767. Bethesda: NIH; 2006.

3. Rapkin L, Pashankar FD. Management of thyroid carcinoma in children and young adults. J Pediatr Hematol Oncol. 2012;34:S39-46.

4. Leboulleux S, Baudin E, Hartl DW, Travagli JP, Schlumberger M. Follicular-cell derived thyroid cancer in children. Eur J Cancer. 2004;40:1655-9.

5. Vaisman F, Corbo R, Vaisman M. Thyroid Carcinoma in children and adolescents - Systematic review of the literature. J Thyroid Res. 2011;2011:845362

6. LaFranchi S. Thyroid nodules and cancer in children. UpToDate. [ac- in several carcinomas, including thyroid. Patients under 45 years of age are classified as stage I (any tumor, any lymph node, no metastasis) or II (any tumor, any lymph node with distant metastases). This may underestimate the malignant potential of these carcinomas in this population. Other prognostic scoring systems may be useful in planning treatment for children, most of whom have AJCC stage 1 disease. ${ }^{5}$ In this population $95 \%$ can be classified as stage 1 or low risk. Despite that, aggressive treatment strategies were employed in most of them (total thyroidectomy in 18, RAI in 16 and suppressive LT4 therapy in all patients). These may have contributed to the overall good results in this cohort. The survival rate was $100 \%$ and, in last appointment, the majority of the patients were free of disease. This study has some limitations. First, this is a retrospective study with its associated difficulties in data collection resulting in missing information in some cases. Also, our hospital is an adult institution and not an oncologic unit which may explain the low annual incidence and the absence of very young children. Despite this, and given the lack of clear international recommendations to guide management the authors think that's important to report the experience accumulated and results achieved.

\section{CONCLUSIONS}

Thyroid carcinoma is rare in children and young adults. This series, including 19 cases, has the advantage of a relatively long follow-up and several conclusions can be made. First, the $100 \%$ survival rate confirmed the overall good prognosis of DTC, similar to that in the literature. Second, and contrary to most of literature data, these patients showed initial rates of lymph node and distant metastases similar to those of adult population $(31.6 \%$ and $5.2 \%$, respectively), not confirming the initial aggressive clinical presentation described in most studies. Finally, adequate initial treatment and long term follow-up were fundamental for good results achieved.

\section{CONFLICT OF INTERESTS}

The authors declare that they have no conflict of interests.

\section{FUNDING SOURCES}

None stated.

cessed on Nov 2012]. Available: http://www.uptodate.com/contents/ thyroid-nodules-and-cancer-in-children?detectedLanguage=en\&source =search result\&translation=Thyroid+nodules+and+cancer+in+children \&search=Thyroid+nodules+and+cancer+in+children\&selectedTitle=1 1 50\&provider=noProvider

7. Rivkees SA, Mazzaferri EL, Verburg FA, Reiners C, Luster M, Breuer $\mathrm{CK}$, et al. The treatment of differentiated thyroid cancer in children: emphasis on surgical approach and radioactive iodine therapy. Endocrine Rev. 2011;32:798-826

8. Malchoff CD, Malchoff DM. The genetics of hereditary nonmedullary thyroid carcinoma. J Clin Endocrinol Metab. 2003;87:2455-9.

9. Cooper DS, Doherty GM, Haugen BR, Kloos RT, Lee SL, Mandel SJ, et al. Revised American thyroid association management guidelines for patients with thyroid nodules and differentiated thyroid cancer. Thyroid. 
2009;19:1167-214.

10. Lazar L, Lebenthal Y, Steinmetz A, Yackobovitch-Gavan M, Phillip M. Differentiated thyroid carcinoma in pediatric patients: comparison of presentation and course between prepubertal children and adolescents. J Pediatr. 2009;154:708-14.

11. Neiva F, Mesquita J, Paco Lima S, Matos MJ, Costa C, Castro-Correia $\mathrm{C}$, et al. Thryroid carcinoma in children and adolescents: a retrospective review. Endocrinol Nutr. 2011;59:105-8.

12. Vieira MS, Marques $P$, Simões Pereira J, Macedo D, Leite V, Limbert
E. Tumores de origem folicular da tiroideia em idade pediátrica: análise retrospectiva de 93 casos. Rev Port Endocrinol Diabetes Metab. 2012;7:88-9.

13. Dinauer C, Francis G. Thyroid cancer in children. Endocrinol Metab Clin N Am. 2007;36:779-806.

14. Baudin E, Do Cao C, Cailleux AF, Leboulleux S, Travagli JP, Schlumberger $\mathrm{M}$, et al. Positive predictive value of serum thyroglobulin levels, measured during the first year of follow-up after thyroid hormone withdrawal, in thyroid cancer patients. J Clin Endocrinol Metab. 2003;88:1107-11. 